\title{
The Role of External Green Supply Chain management on Green Marketing Mix toward Sustainability of Petrochemical Industry in Indonesia
}

\author{
Yuary Farradia $^{1}$, Abdul Talib Bon ${ }^{2}$, Hari Muharam ${ }^{3}$ \\ \{juaryfarradia@yahoo.com ${ }^{1}$, talib@uthm.edu.my ${ }^{2}$, hari.muharam@unpak.ac.id ${ }^{3}$ \} \\ Faculty of Economics - Universitas Pakuan - Bogor, Indonesia ${ }^{1,3}$ Faculty of Technology and \\ Management - Universiti Tun Hussein Onn - Malaysia ${ }^{1,2}$
}

\begin{abstract}
An effort on study and innovation toward green industry is one of the Indonesia government focus for the petrochemical industry. This green industry target is in line with the aim of sustainability in the petrochemical industry in Indonesia. Implementation of green supply chain management has been recommended from most study of sustainability. There is external green supply chain management consist of green purchasing and reverse logistics which play important role in relate to both customer and supplier subject to greening the supply chain management practice. This green practice then be informed to the customer trough the green marketing mix practices which finally will contribute to the firm sustainability. This study focuses only for the Olefin petrochemical group located in Banten province Indonesia. To improve the sustainability of petrochemical industry mainly in olefin area, it is need to implement the external green supply chain management such green purchasing and reverse logistic and green marketing mix
\end{abstract}

.Keywords: External Green supply chain management, Green Purchasing, Reverse Logistic, Sustainability, Green Marketing Mix

\section{Introduction}

There are economic indicators can be used to draw current level of the business operations which can be used to describe how business is managed subject to economic perspective of triple bottom line (TBL) dimension of sustainability. Economic as one of the TBL dimension reflects the organizational success in achieving the needs of either the owners or the shareholders (Sridhar, 2012).

Both environmental dimension of TBL and sustainability issues are always take the most attention for modern humanity and governments, in particular for the emerging economies subject to organizational sustainability, (Hsu et al., 2013; Fabbe-Costes et al., 2014; Tseng et al., 2015). According to Dubey et al. (2015) and Zhu et al. (2012), indeed the adoption of GSCM practices was increased due to enforcement by the regulatory bodies.

The social dimension of TBL relates to corporate social responsibility (CSR). Elkington (1997) stated that this dimension measures any organization's impact on the social systems of the community within national or global level.

The implementation of environmental practices relates to organizations in terms of supply chain and their business environments (Kim \& Chai, 2017). The external Green Supply Chain Management/ GSCM which relates to the external factor of a firm such as supplier and 
customer can improve firm performance once it implemented after the internal GSCM (Zhu,et al., 2020. According to Chavez et al. (2014), manufacturers that implement customer-centric GSCM can reduce cost and improve quality, delivery, and flexibility. Thus, the external GSCM practices used in this study are referred to green purchasing (GP), green logistics (GL) and reverse logistics (RL).

This external GSCM dimension focuses on purchasing and procurement functions within an organization, it also represents the 'upstream' portion of the supply chain. Purchasing activities relate to specific responsibilities such as selection on both vendor and material, outsourcing, negotiation, buying, delivery scheduling, inventory and materials management and to some extent, involvement in design. In fact, the focus of supplier management is mainly refer to responsibility of the purchasing and procurement department (Sarkis, 2014).

GP focus on the procurement of products and services activities in order to reduce any effect on human health and environment which can be compared with competing products or services that serve the same purpose (Vishal \& Avinash, 2016). Furthermore, consumers have the ability to prevent or minimize environmental destruction by purchasing green products. In conjunction, prior study indicates that consumers responds positively towards environmental protection (Liu et al., 2012).

The other stages in external GSCM practices and functions which relate to the customer are reverse logistics. An appropriate reverse logistics system could be designed toward operation efficiency because it is focus on both environmental and economic aspects (Govindani et al., 2015). The main objective of reverse logistics is to maximize after sales activities such as customer service, quality evaluation and warehousing so that can generate additional source of income, increase customer satisfaction and of the environment conservation (Christopher, 2016). Refund, restock, refurbish and recycle are known as the basis of reverse logistics, namely 4R (Murray, 2012).

Previous study done by Hashem \& Rifai (2011) in three Arab States in West Asia, concluded, that applying green marketing mix elements by the chemical industries companies in three countries on consumer's mental image is significant, and suggested that such chemical manufacturers should improve their products development focus by adding environmentally friendly products, whilst raising public awareness of green marketing importance in chemical industries companies.

Rath (2013) describes those products that are manufactured from the industry through the green technology and caused no environmental hazards are called "Green Products". Green products will impact to its bottom line. Indeed, environmentally aware consumers tend to earn more and are willing to pay more for green products.

Green pricing aimed to create pricing practices that concern on both the economic and environmental costs of production and marketing, while generate value for customers and a fair profit for business (Martin \& Schouten, 2012). Green pricing which refer to the environmental friendliness is important because it can be added to the product in order to enhance its appearance, functionality and customization (Shrama \& Goyal, 2012).

Chin et al. (2015) identified that green distribution has various benefit which able to reducing energy consumption in warehouses. Furthermore, green distribution able to contribute an improvement of the overall firm performance as well as better corporate image. The results study of Chin et al. (2015) concluded that green distribution has both significant and positive impact on the environmental performance of industrial firms in Malaysia.

Hasan \& Ali (2017) stated that green promotion act as media of communication that promotes the product and the services as well as green advertising campaign to enhance the 
corporate image of social responsibility. Implementation of both green innovation and green promotion will influence the firms' performance.

\section{$\underline{\text { Hypotheses Development }}$}

The research hypotheses as follow:

$\mathrm{H}_{1}$ : There is a direct positive effect of External GSCM on economic performance

$\mathrm{H}_{2}$ : There is a direct positive effect of External GSCM on environment performance

$\mathrm{H}^{3}$ : There is a direct positive effect of External GSCM on social performance

$\mathrm{H}^{4}$ : There is a positive effect of Green Marketing Mix on economic performance

$\mathrm{H}_{5}$ : There is a positive effect of Green Marketing Mix on environment performance

$\mathrm{H}^{6}$ : There is a positive effect of Green Marketing Mix on social performance

$\mathrm{H}_{7}$ : There is a positive effect of External GSCM on green marketing mix

$\mathrm{H}_{8}$ : Green marketing mix mediate the External GSCM to economic performance

$\mathrm{H}_{9}$ : Green marketing mix mediate the External GSCM to environment performance

$\mathrm{H}_{10}$ : Green marketing mix mediate the External GSCM to social performance

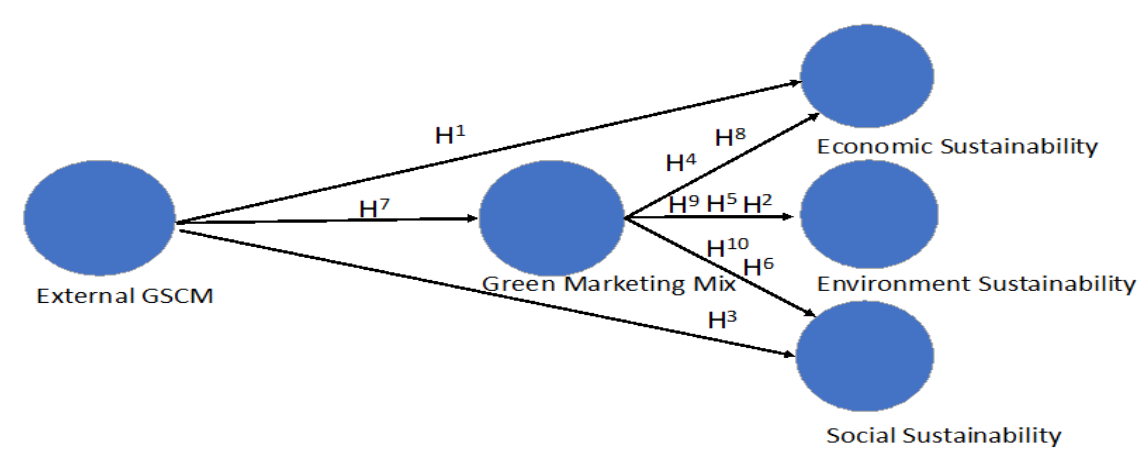

Figure 1 Conceptual Model Hypothesis

\section{Method}

This study focuses only for the Olefin petrochemical group located in Banten province Indonesia. Data collection is based on cluster random sampling. The total number of respondents in this study are 296. Having data screening form outliers by SPSS then the data ready for measurement analysis is 255 . 
The concepts of external GSCM practices will be measured by quantitative approach. SPSS statistic tools is used for data screening, and descriptive statistics, whilst smart PLS 3 of the structural equation model (SEM) is used to test model hypotheses. The research model of this study consists a higher order construct.

\section{Result and Discussions}

Table 1 present the hypothesis evaluation shown that the external GSCM has positive relationship with both economic and environment sustainability only. Whilst the GMM has positive relationship with all the sustainability dimension. However, external GSCM has positive relationship with GMM. On the other side, table 2 present that mediation was significant plays a role in the relationship between external GSCM with sustainability.

Table.1 Hypothesis result

\begin{tabular}{|c|c|c|c|c|c|c|c|c|c|}
\hline $\begin{array}{l}\text { Hypo- } \\
\text { thesis }\end{array}$ & Description & $\begin{array}{c}\text { Standard } \\
\text { Beta }\end{array}$ & $\begin{array}{l}\text { Standard } \\
\text { Error }\end{array}$ & $\begin{array}{c}t- \\
\text { value }\end{array}$ & $\begin{array}{c}\mathrm{p}- \\
\text { value }\end{array}$ & $\begin{array}{c}\text { Conclusio } \\
\mathbf{n}\end{array}$ & $\left(\mathbf{R}^{2}\right)$ & $\left(f^{2}\right)$ & $\left(Q^{2}\right)$ \\
\hline $\mathrm{H}_{1}$ & $\begin{array}{l}\text { EXTERNAL GSCM } \\
\rightarrow \\
\text { SUSTAINABILITY } \\
\text { ECONOMIC } \\
\text { PERFORMANCE }\end{array}$ & 0.259 & 0.067 & 3.855 & 0.000 & Supported & & 0.062 & \\
\hline $\mathrm{H}_{2}$ & $\begin{array}{l}\text { EXTERNAL GSCM } \\
\vec{\rightarrow} \\
\text { SUSTAINABILITY } \\
\text { ENVIRONMENT } \\
\text { PERFORMANCE }\end{array}$ & 0.140 & 0.081 & 1.734 & 0.042 & Supported & & 0.014 & \\
\hline $\mathrm{H}_{3}$ & $\begin{array}{l}\text { EXTERNAL GSCM } \\
\overrightarrow{ } \\
\text { SUSTAINABILITY } \\
\text { SOCIAL } \\
\text { PERFORMANCE }\end{array}$ & 0.077 & 0.085 & 0.906 & 0.183 & $\begin{array}{l}\text { Not } \\
\text { Supporte } \\
\text { d }\end{array}$ & & 0.004 & \\
\hline $\mathrm{H}_{4}$ & $\begin{array}{l}\text { GREEN } \\
\text { MARKETING MIX } \\
\rightarrow \text { SUSTAINABILIT } \\
\text { Y ECONOMIC } \\
\text { PERFORMANCE }\end{array}$ & 0.540 & 0.082 & 6.547 & 0.000 & Supported & 0.494 & 0.199 & 0.296 \\
\hline $\mathrm{H}_{5}$ & $\begin{array}{l}\text { GREEN } \\
\text { MARKETING MIX } \\
\rightarrow \text { SUSTAINABILIT } \\
\text { Y ENVIRONMENT } \\
\text { PERFORMANCE }\end{array}$ & 0.574 & 0.089 & 6.414 & 0.000 & Supported & 0.322 & 0.168 & 0.234 \\
\hline $\mathrm{H}_{6}$ & $\begin{array}{l}\text { GREEN } \\
\text { MARKETING MIX } \\
\vec{\rightarrow} \\
\text { SUSTAINABILITY } \\
\text { SOCIAL } \\
\text { PERFORMANCE }\end{array}$ & 0.238 & 0.104 & 2.294 & 0.011 & Supported & 0.309 & 0.028 & 0.217 \\
\hline $\mathbf{H}_{7}$ & $\begin{array}{l}\rightarrow \text { GREEN } \\
\text { MARKETING MIX }\end{array}$ & 0.290 & 0.059 & 4.897 & 0.000 & Supported & 0.634 & 0.128 & 0.463 \\
\hline
\end{tabular}


Table 2. Hypothesis on Mediation

\begin{tabular}{|c|c|c|c|c|c|c|c|c|}
\hline \multirow{2}{*}{$\begin{array}{l}\text { Hypo- } \\
\text { thesis }\end{array}$} & \multirow{2}{*}{ Description } & \multirow{2}{*}{$\begin{array}{l}\text { Standard } \\
\text { Beta }\end{array}$} & \multirow{2}{*}{$\begin{array}{l}\text { Standar } \\
\text { d Error }\end{array}$} & \multirow{2}{*}{$\begin{array}{l}\text { T Statistics } \\
(\mid \mathrm{O} / \mathrm{STDEV})\end{array}$} & \multirow{2}{*}{$\begin{array}{l}\mathrm{P} \\
\text { Values }\end{array}$} & \multicolumn{2}{|c|}{$\begin{array}{l}\text { Confidence Interval } \\
\text { (BC) }\end{array}$} & \multirow{2}{*}{ Decision } \\
\hline & & & & & & $\begin{array}{l}2.5 \% \\
(\mathrm{LL})\end{array}$ & $\begin{array}{l}97.5 \% \\
\text { (UL) }\end{array}$ & \\
\hline $\mathrm{H}_{\mathrm{s}}$ & $\begin{array}{l}\text { EXTERNAL } \\
\text { GSCM } \rightarrow \\
\text { GREEN } \\
\text { MARKETING } \\
\text { MIX }> \\
\text { ECONOMIC } \\
\text { PERFORMAN } \\
\text { CE }\end{array}$ & 0.157 & 0.042 & 3.705 & 0.000 & 0.084 & 0.250 & $\begin{array}{l}\text { Supporte } \\
\text { d }\end{array}$ \\
\hline $\mathrm{H}_{9}$ & $\begin{array}{l}\text { EXTERNAL } \\
\text { GSCM }> \\
\text { GREEN } \\
\text { MARKETING } \\
\text { MIX - } \\
\text { ENVIRONME } \\
\text { NT } \\
\text { PERFORMAN } \\
\text { CE } \\
\end{array}$ & 0.167 & 0.044 & 3.761 & 0.000 & 0.091 & 0.266 & Supporte \\
\hline $\mathrm{H}_{10}$ & $\begin{array}{l}\text { EXTERNAL } \\
\text { GSCM }> \\
\text { GREEN } \\
\text { MARKETING } \\
\text { MIX }> \\
\text { SOCIAL } \\
\text { PERFORMAN } \\
\text { CE }\end{array}$ & 0.069 & 0.034 & 2.046 & 0.041 & 0.013 & 0.142 & $\begin{array}{l}\text { Supporte } \\
\text { d }\end{array}$ \\
\hline
\end{tabular}

Based on the hypothesis result it can be seen that the green purchasing and reverse logistic are play important role in relate to both customer and supplier subject to greening the supply chain management practice. This green practice then be informed to the customer trough the green marketing mix practices which finally will contribute to the firm sustainability.

\section{Conclusion}

To improve the sustainability of petrochemical industry mainly in olefin area, it is need to implement the external GSCM covers green purchasing and reverse logistic and GMM. Thus External GSCM and GMM plays the main role toward sustainability in petrochemical industry in Indonesia.

\section{Acknowledgement}

This research has been benefiting from the Universiti Tun Hussein Onn Malaysia and Universitas Pakuan, Bogor - Indonesia. Some direct observation and preliminary interview are contributed from various manufacturers in Banten Province - Indonesia.

\section{References}

[1] Bhalerao \& Deskhmuh. (2015). Green Marketing: Greening the 4 Ps of Marketing. International Journal of Knowledge and Research in Management \& E-Commerce, Vol.5, Issue 2, April, 2015.p $5-8$.

[2] Govindan , K., Soleiman, H. and Kannan, D. (2015). Reverse logistics and closed- 
[3] loop supply chain: A comprehensive review to explore the future. European Journal of Operational Research, Vol. 240, No. 3, pp. 603-626.

[4] Indonesia Development Regulation no 14, (2015)

[5] Hasan, Z and Ali, N.A., (2017). Modelling the Relationship Between Green Marketing Strategies and Performance Outcomes for Business Sustainability. Global Conference on Business and Economics Research (GCBER). 14-15 August 2017, Universiti Putra Malaysia, Malaysia Available online at August 14-15, UPM, Malaysia

[6] Hsu, C., Tan, K.C., Zailani, S.H.M. and Jayaraman, V. (2013). Supply Chain Drivers that Foster the Development of Green Initiatives in An Emerging Economy, International Journal of Operations \& Production Management, Vol. 33 No. 6, pp. 656-688

[7] Kim, M., and Chai, S. (2017). Implementing Environmental Practice for Accomplishing Sustainable Green Supply Chain Management. Sustainability, 9, pp. 1192

[8] Liu, X., Wang, C., Shishime, T., and Fujitsuka, T. (2012). Sustainable Consumption: Green Purchasing Behaviours of Urban Residents Chine. Sustainable Development, 20 (4), pp. 293 - 308.

[9] Sarkis, J. (2014). Green Supply Chain Management. ASME, New York.

[10] Vishal, M.S., \& Avinash, S,. (2016). Green Supply Chain Management - An Overview. International Journal of Advanced Engineering and Innovative Technology (IJAEIT). ISSN No 2348-7208. Special Issue on "Emerging Technology for Innovative India".

[11] Zhu, Q., Sarkis, J,. Lai, K. (2012). Examining the Effects of Green Supply Chain Management Practices and Their Mediations on Performance Improvements. International Journal of Production Research, 50 (50), pp. 1377 - 1394. 